\title{
Putative Postmeiotic Segregation Increased 2-Like Protein 1
}

National Cancer Institute

\section{Source}

National Cancer Institute. Putative Postmeiotic Segregation Increased 2-Like Protein 1. NCI Thesaurus. Code C34069.

Putative postmeiotic segregation increased 2-like protein 1 (440 aa, $\sim 48 \mathrm{kDa}$ ) is encoded by the human PMS2L1 gene. This protein may play a role in DNA repair. 